\title{
Determination of the Concentration of Selected Heavy Metals in Indigenous Plant: Telfairia occidentalis
}

\author{
Adepoju-Bello AA ${ }^{1}$, Okeke $\mathrm{CP}^{1}$, Bamgbade I' and Oguntibeju OO ${ }^{2 *}$ \\ ${ }^{1}$ Pharmaceutical Chemistry Department, Faculty of Pharmacy, University of Lagos, Southern Nigeria \\ ${ }^{2}$ Department of Biomedical Sciences, Faculty of Health and Wellness Sciences, Cape Peninsula University of Technology, Bellville Campus, 7535, South Africa
}

\begin{abstract}
Telfairia occidentalis Hook. F. is an edible vegetable, rich in essential diet components and contains protein, vitamins, iron, calcium and other nutrients, which are not adequately supplied in our diet. However, Telfairia occidentalis is believed to contain heavy metals over a range of concentrations which could pose potential health risk to the consumers. The objective of this study was to determine whether the concentration of selected heavy metals present in Telfairia occidentalis cultivated in twenty Local Government areas of Lagos State, Nigeria, are within the acceptable range for human consumption. Telfairia occidentalis leaf samples were collected from twenty local government areas in Lagos State, washed thrice with water and air-dried prior to grounding into fine powder and sieved. The samples were digested with concentrated $\mathrm{HNO}_{3}$ and the concentrations of the metals were determined using the Buck 205 Atomic Absorption Spectrophotometer. The British Pharmacopoeia calibration plot method was adopted. All the Telfairia occidentalis samples (100\%) from the 20 Local Governments in Lagos State contained arsenic and mercury below the USP oral component limit while $100 \%$ contained cadmium above the oral component limit. Twenty percent (20\%) contained iron above the USP oral component limit. These metals could bio-accumulate in the biological system of people consuming this vegetable, thus posing potential health risk to consumers especially if consumed over a long period. We therefore suggest regular assessing of these metals in vegetables grown in these localities and that government should monitor and ensure proper disposal of waste within the environment in order to reduce the level of contamination of vegetables by heavy metals which are mainly resulting from industrial wastes and other sources of environmental pollution.
\end{abstract}

Keywords: Vegetable; Contamination; Heavy metals; Health hazards

\section{Introduction}

Telfaira occidentalis Hook generally known as fluted pumpkin occurs in the forest zone of West and Central Africa, mostly in Benin, Nigeria and Cameroon. It is a popular vegetable all over Nigeria. It is rare in Uganda and absent in the rest of East Africa. It is believed that it originated in south-east Nigeria and was distributed by the Igbos who had cultivated it for centuries. The plant produces luxuriant edible green leaves which are rich in iron and vitamins. Stems of the plants have branching, long twisting tendrils and the leaves are divided into three to five leaflets with the terminal leaflets measuring $15 \mathrm{~cm}$ in length and the male plant is grown mainly for leaves and seeds and form important soup ingredients in Nigeria [1-4].

Recent studies have shown that Telfairia occidentalis leaf is rich in minerals such as iron, potassium, sodium, phosphorus, calcium and magnesium and antioxidant vitamins such as thiamine, riboflavin and ascorbic acid and phytochemicals such as phenols [5-8]. The young leaves sliced and mixed with coconut water and salt are stored in a bottle and used for the treatment of convulsion in ethno medicine [4]. The leaf extract is used in the management of cholesterolemia, liver problems and impaired immune system. It has been reported that its amino acid contents compared favourably with those of important legumes. The study of Emeka and Obidoa [9] reveals that long-term feeding of T. occidentalis-supplemented diet caused a significant increase in weight of the animals which may be attributed to its rich nutritional contents. An anecdotal report has it that T. occidentalis leaf is a key ingredient in most Nigerian soups and the high vegetable content provides high dietary fibre, good for sound bowel function and ideal in a weight control diet $[4,10,11]$.

Various vegetables abound in Nigeria which is utilized either as condiments or spices in human diets and these vegetables could be harvested at all stages in the process of growth and could be used either in the fresh, processed or semi-processed form. However, the presence of inherent toxic metals has been implicated as one of the variables affecting the nutritional values of food. Although a lot of information could be available about the nutrient and antinutrient contents of these commonly consumed green leafy vegetables in Nigeria, there is a dearth of information with regard to their safety. It is known that vegetables take up metals by absorbing them from contaminated soils, as well as from deposits on different parts of the vegetables exposed to the air from polluted environments [6,12]. It has been reported that nearly half of the means of ingestion of lead, cadmium and mercury through food is due to plant origin (fruit, vegetables and cereals). Moreover, some population groups seem to be more exposed, especially vegetarians, since they absorb more frequently 'tolerable daily doses'. Food contamination by heavy metals depends both on their mobility in the soil and their bioavailability $[3,13]$.

Iron is one of the elements present in T. occidentalis and iron is very important for blood building but when in excess it becomes toxic and causes iron overload disease known as haemochromatosis. Large amounts of ingested iron can cause excessive levels of iron in the blood.

*Corresponding author: Oluwafemi Oguntibeju, Department of Biomedical Sciences, Faculty of Health and Wellness Sciences, Cape Peninsula University of Technology, Bellville Campus, 7535, South Africa, Tel: +27219538495; Fax: +27219538490; E-mail: oguntibejuo@cput.ac.za, bejufemi@yahoo.co.uk

Received July 05, 2013; Accepted August 16, 2013; Published August 19, 2013

Citation: Adepoju-Bello AA, Okeke CP, Bamgbade I, Oguntibeju OO (2013) Determination of the Concentration of Selected Heavy Metals in Indigenous Plant: Telfairia occidentalis. Altern Integ Med 2: 137. doi:10.4172/2327-5162.1000137

Copyright: (c) 2013 Adepoju-Bello AA, et al. This is an open-access article distributed under the terms of the Creative Commons Attribution License, which permits unrestricted use, distribution, and reproduction in any medium, provided the original author and source are credited. 
High blood levels of free ferrous iron react with peroxides to produce free radicals, which are highly reactive and can damage DNA, proteins, lipids, and other cellular components. Thus, iron toxicity occurs when there is free iron in the cell, which generally occurs when iron levels exceed the capacity of transferrin to bind the iron. Damage to the cells of the gastrointestinal tract can also prevent them from regulating iron absorption leading to further increase in blood levels. Iron typically damages cells in the heart, liver and elsewhere, which can cause significant adverse effects, including coma, metabolic acidosis, shock, liver failure, coagulopathy, adult respiratory distress syndrome, longterm organ damage, and even death $[1,14,15]$. It should be noted these metals constitute health risk to consumers because they bio-accumulate in the body when ingested via fluids, food or through other sources of contamination and are stored faster than they are excreted [16,17]. Heavy metal toxicity can result in damaged or reduced mental and central nervous function, lower energy levels, and damage to blood composition, lungs, kidneys, liver, and other vital organs. A longterm exposure may result in slowly progressive physical, muscular, and neurological degenerative processes that mimic Alzheimer's disease, muscular dystrophy, and multiple sclerosis. Allergies are not uncommon and repeated long-term contact with some metals or their compounds may cause cancer $[18,19]$. For some metals, toxic levels can be just above the background concentrations naturally found in nature, therefore, it is important to inform consumers about health-risk associated with consuming products/contaminated with heavy metals and to take protective measures against excessive exposure [16].

Due to the high consumption of Telfairia occidentalis in our community, there is a need to analyse the concentrations of heavy metals in these vegetable samples. In this study, the concentrations of some heavy metals: arsenic, cadmium, mercury and iron in the leaves of Telfairia occidentalis Hook. F. was determined using the Atomic Absorption Spectrophotometric (AAS) method.

\section{Materials and Methods}

\section{Study area and sample collection}

The samples of Telfaira Occidentalis were randomly collected from 20 Local Governments in Lagos State, Nigeria (Ikeja, Ikorodu West, Badagry West, Mushin, Ketu, Ojota, Oshodi, Shomolu, Ikoyi, Badagry, Ikorodu North, Isolo, Ojo, Epe, Alimosho, Ipaja, Yaba, Bariga, Itire Ikate, and Ejigbo).

\section{Pre-Treatment of samples}

The collected vegetable samples were washed thrice with distilled water to remove dust particles. The leaves were air-dried. The dried samples were ground into a fine powder and stored in polyethylene bags, until used for acid digestion.

\section{Sample preparation}

$1.0 \mathrm{~g}$ of each sample was taken into $250 \mathrm{mls}$ conical flask and $10 \mathrm{mls}$ of conc. $\mathrm{HNO}_{3}$ (GFS Chemicals Inc., Columbus, 69\%) was added and the mixture was evaporated on the hot plate in a fume cupboard until the brown fumes disappeared giving the white fumes. The samples were then made up to $50 \mathrm{mls}$ mark with deionised water and filtered. The digested samples were stored in bottles ready for analysis.

\section{Reference sample preparation}

The metal ion standard solutions were prepared from 1000 ppm GFS (Fisher's AAS Reference Standard). A 100 ppm of metal ion solution was prepared from $1000 \mathrm{ppm}$ reference standard. Serially diluted concentrations of $2 \mathrm{ppm}, 4 \mathrm{ppm}, 6 \mathrm{ppm}, 8 \mathrm{ppm}$ and $10 \mathrm{ppm}$ were prepared.

\section{Sample analysis}

The Atomic Absorption Spectrophotometric (AAS) method was used for the analysis and the British Pharmacopoeia calibration plot method was adopted [20]. A Buck 205 atomic absorption spectrophotometer was used for the quantification of metal ions and was used in the analysis of iron and cadmium. A hydride generator was attached to the atomic absorption spectrophotometer for the quantification of Arsenic. The cold vapour technique was attached to the AAS for the analysis of mercury [21]. The absorbance for the standard solution was obtained and a calibration graph was plotted. The digested sample solutions were analysed in triplicates. The concentrations of the digested samples were obtained from the regression equation derived from the calibration plot using Microsoft Excel software. All chemicals and reagents used were of analytical grade.

\section{Result and Discussion}

The results obtained from this study are summarized in (Tables 1 and 2 and Figure 1) below. All the metal ions $\mathrm{Hg}^{2+}, \mathrm{Cd}^{2+}, \mathrm{As}^{2+}$ and $\mathrm{Fe}^{2+}$ analysed were present in all the vegetable samples. The concentrations of iron and cadmium were higher in vegetable samples obtained from Ikeja. However, in all, iron reflect the highest concentrations of metals reported in the leaves of T. occidentalis, particularly so in the Ikeja area.

The accumulation of heavy metals in agricultural soils is of increasing concern because of food safety issues, potential health risks and its detrimental effects on soil ecosystem [22]. Mercury and cadmium are of great concern because of their toxicity to human health and other organisms. Vegetables are known to take up mercury while lead and cadmium accumulate them in their edible and nonedible parts of vegetables. The intake of the edible parts of vegetables is an important path for heavy metals in the soil to cause harm to human health. In this study, the concentrations of toxic metals were determined and we found that the levels of iron in the samples ranged

\begin{tabular}{|l|l|l|l|l|}
\hline $\begin{array}{l}\text { Different } \\
\text { locations in } \\
\text { Lagos state }\end{array}$ & $\begin{array}{l}\mathbf{H g}^{2+} \\
\mathbf{m g} / \mathbf{k g} \pm \mathbf{S D}\end{array}$ & $\begin{array}{l}\mathbf{C d} \\
\mathbf{m g} / \mathbf{k g} \pm \mathbf{S D}\end{array}$ & $\begin{array}{l}\mathbf{A s}^{2+} \\
\mathbf{m g} / \mathbf{k g} \pm \mathbf{S D}\end{array}$ & $\begin{array}{l}\mathbf{F e}^{2+} \\
\mathbf{m g} / \mathbf{k g} \pm \mathbf{S D}\end{array}$ \\
\hline Ikeja & $0.417 \pm 0.0006$ & $5.233 \pm 0.0025$ & $0.983 \pm 0.0015$ & $29.367 \pm 0.0015$ \\
\hline Ikorodu west & $0.517 \pm 0.0006$ & $4.150 \pm 0.0044$ & $0.900 \pm 0.002$ & $21.617 \pm 0.0006$ \\
\hline Badagry west & $0.533 \pm 0.0006$ & $1.183 \pm 0.0025$ & $0.867 \pm 0.0015$ & $5.617 \pm 0.0006$ \\
\hline Mushin & $0.733 \pm 0.0006$ & $2.750 \pm 0.001$ & $0.933 \pm 0.0015$ & $4.333 \pm 0.0006$ \\
\hline Ketu & $0.567 \pm 0.0006$ & $1.283 \pm 0.0015$ & $0.883 \pm 0.0040$ & $4.967 \pm 0.0006$ \\
\hline Ojota & $0.500 \pm 0.001$ & $2.000 \pm 0.0035$ & $1.017 \pm 0.0015$ & $2.367 \pm 0.0015$ \\
\hline Oshodi & $0.467 \pm 0.0006$ & $2.183 \pm 0.0006$ & $1.100 \pm 0.002$ & $6.383 \pm 0.0006$ \\
\hline Shomolu & $0.517 \pm 0.0006$ & $2.533 \pm 0.0006$ & $1.200 \pm 0.002$ & $5.750 \pm 0.001$ \\
\hline Ikoyi & $0.467 \pm 0.0006$ & $3.100 \pm 0.0010$ & $0.967 \pm 0.0038$ & $3.250 \pm 0.0036$ \\
\hline Badagry & $0.35 \pm 0.0000$ & $2.633 \pm 0.0021$ & $1.117 \pm 0.0085$ & $1.250 \pm 0.002$ \\
\hline Ikorodo north & $0.433 \pm 0.0006$ & $1.117 \pm 0.0021$ & $0.900 \pm 0.002$ & $1.117 \pm 0.0015$ \\
\hline Isolo & $0.467 \pm 0.0006$ & $2.133 \pm 0.0015$ & $0.900 \pm 0.0036$ & $0.683 \pm 0.0025$ \\
\hline Ojo & $0.550 \pm 0.0006$ & $1.550 \pm 0.0010$ & $0.883 \pm 0.0006$ & $3.050 \pm 0.001$ \\
\hline Epe & $0.550 \pm 0.0006$ & $1.367 \pm 0.0015$ & $1.050 \pm 0.0026$ & $2.533 \pm 0.0006$ \\
\hline Alimosho & $0.617 \pm 0.0006$ & $3.567 \pm 0.0015$ & $1.050 \pm 0.0017$ & $2.617 \pm 0.0015$ \\
\hline Ipaja & $0.500 \pm 0.001$ & $0.667 \pm 0.0021$ & $1.050 \pm 0.0017$ & $2.067 \pm 0.0006$ \\
\hline Yaba & $0.433 \pm .0006$ & $0.917 \pm 0.0006$ & $1.067 \pm 0.0015$ & $1.683 \pm 0.0021$ \\
\hline Bariga & $0.433 \pm 0.0006$ & $0.817 \pm 0.0006$ & $1.183 \pm 0.0035$ & $1.750 \pm 0.0095$ \\
\hline Itire ikate & $0.367 \pm 0.0006$ & $1.117 \pm 0.0012$ & $1.050 \pm 0.0026$ & $1.383 \pm 0.0042$ \\
\hline Ejigbo & $0.400 \pm 0.0000$ & $1.733 \pm 0.0015$ & $1.050 \pm 0.002$ & $2.167 \pm 0.0015$ \\
\hline
\end{tabular}

Table 1: Mean concentration of metal ions $(\mathrm{mg} / \mathrm{kg} \pm \mathrm{SD})$ in Telfaria occidentalis. 


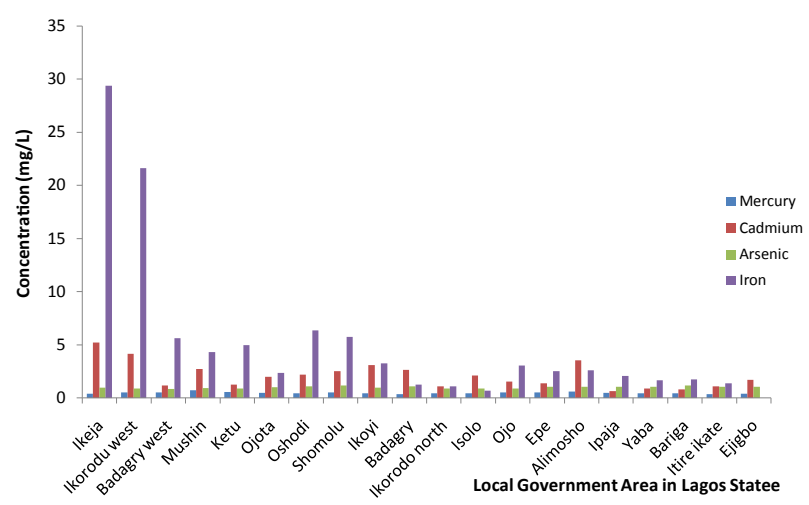

Figure 1: Concentration of Metal ions of Telfaira occidentalis from Twenty Local Government in Lagos State.

\begin{tabular}{|l|l|l|l|l|}
\hline Metal ion & $\mathbf{A s}^{2+}$ & $\mathbf{C d}^{2+}$ & $\mathbf{F e}^{2+}$ & $\mathbf{H g}^{2+}$ \\
\hline Number of Local Government Areas & 20 & 20 & 20 & 20 \\
\hline Number of samples with detectable metal ions & 20 & 20 & 20 & 20 \\
\hline \% of samples with detectable metal ions & $100 \%$ & $100 \%$ & $100 \%$ & $100 \%$ \\
\hline Minimum conc. of metal ion detected $(\mu \mathrm{g} / \mathrm{g})$ & 0.883 & 0.667 & 0.683 & 0.35 \\
\hline Maximum conc. of metal ions detected $(\mu \mathrm{g} / \mathrm{g})$ & 1.183 & 5.233 & 29.36 & 0.733 \\
\hline USP Oral Component Limits $(\mathrm{OCL})(\mu \mathrm{g} / \mathrm{g})$ & 1.5 & 0.5 & 5.0 & 1.5 \\
\hline Number of samples above USP OCL & 0 & 20 & 5 & 0 \\
\hline \% above USP Limits & 0 & $100 \%$ & 25 & 0 \\
\hline
\end{tabular}

Table 2: Summary of the atomic absorption characteristics of arsenic, cadmium, iron and mercury metal ions.

from $0.683 \pm 0.0025 \mathrm{mg} / \mathrm{kg}$ to $29.367 \pm 0.0015$. The maximum safe level of iron reported by the European Economic Commission is $5 \mathrm{mg} / \mathrm{kg}$. We observed in this study that the concentration of $\mathrm{Fe}^{2+}$ in the samples analysed is very high (Table 1 and Figure 1), specifically from Ikeja local government area. This local government area is highly industrialised compared to the other areas and this may possibly explain the higher concentration of iron observed in the leaves of T. occidentalis from Ikeja area. The large amounts of ingested iron can cause excessive levels of iron in the blood and high blood levels of free ferrous iron react with peroxides to produce free radicals, which are highly reactive and can damage DNA, proteins, lipids, and other cellular components [23]. It is a common practice in this community to squeeze out pumpkin water extract for drinking to build up blood level in the human body. It is usually taken with liquid milk and malt drink, thus making high level of iron in the leaves of T. occidentalis more disturbing especially for individuals consuming the plant over a long period.

The concentration of cadmium in the samples ranged from 0.667 \pm 0.0021 to $5.233 \pm 0.0025$. The maximum level of cadmium allowable in leafy vegetables by the European Economic Commission [24], is 0.2 $\mathrm{mg} / \mathrm{kg}$. The result revealed the presence of cadmium in the vegetable from each local government area. In comparison to the average mean concentrations of cadmium in each of the local government area, with the maximum safe levels reported by the European Economic Commission, our results showed that the concentrations of cadmium found in T. occidentalis from each of the local government area were above the recommended maximum level. This is disturbing considering the health implications this may have on the consumers. It is known that exposure to cadmium generally occur in industrialized areas and chronic exposure to cadmium can result in chronic obstructive lung disease, renal disease, and fragile bones.
The concentration of arsenic in the samples ranged from $0.883 \pm$ 0.0006 to $1.183 \pm 0.0035$. The maximum level of arsenic allowable in leafy vegetables by the European Economic Commission is $0.1 \mathrm{mg} / \mathrm{kg}$. The result revealed the presence of arsenic in the vegetables from each local government area. In comparison to the average concentrations of arsenic in each of the local government area, with the maximum safe levels reported by the European Economic Commission, the concentration of arsenic in each of the local government area was above the recommended maximum level. Exposure to arsenic occurs mostly near hazardous waste sites, or in areas with high natural levels. Chronic or lower levels of exposure can lead to progressive peripheral and central nervous changes, such as sensory changes, numbness and tingling, and muscle tenderness [15].

The concentration of mercury in the samples ranged from 0.3500 $\pm 0.0000 \mathrm{mg} / \mathrm{kg}$ to $0.733 \pm 0.0006 \mathrm{mg} / \mathrm{kg}$. The maximum safe level for mercury documented by the European Economic Commission Regulation is $0.01 \mathrm{mg} / \mathrm{kg}$. The vegetables analysed showed higher levels and we are therefore tempted to report that these vegetable may constitute health hazards to human health.

\section{Conclusion}

Vegetables are very important part of a diet. With increasing health consciousness and the growing number of vegetarians nowadays, vegetable safety is a very important issue. Intake of food results in longterm body accumulation of heavy metals and the detrimental impact becomes apparent only after several years of exposure. The results from this study showed that the levels of heavy metals reported in the leaf of T. occidentalis, a commonly consumed vegetable poses potential health risk to consumers. Most of the high concentration of the metals was found in pumpkin leaf cultivated in Ikeja possibly because of the industrial nature of Ikeja. Therefore, we strongly recommend that people living in this area should not eat large quantity of pumpkin leaf so as to avoid excessive accumulation of heavy metals in the body.

\section{References}

1. Dina OA, Adedapo AA, Oyinloye OP, Saba AB (2006) Effect of Telfairia occidentalis extract on Experimentally-induced anaemia in domestic animals. Afri J Biomed Res 3: 181-183.

2. Fasuyi AO, Nonyerem AD (2007) Biochemical, nutritional and haematologica implications of Telfairia occidentalis leaf meal as protein supplement in broiler starter diets. Afri J Biotech 6: 1055-1063.

3. Dike MC (2010) Proximate, phytochemical and nutrient compositions of some fruits, seeds and leaves of some plant species at Umudike, Nigeria. J Agric \& Biol Sc 5: 7-16.

4. Kayode AAA, Kayode OT (2011) Some medicinal values of Telfairia occidentalis: a review. Am J Biochem \& Mol Biol 1: 30-38.

5. Oboh G, Akindahunsi AA (2004) Change in the ascorbic acid, total phenol and antioxidant activity of sun-dried commonly consumed green leafy vegetables in Nigeria. Nutr Health 18: 29-36.

6. Oboh G (2005) Hepatoprotective property of ethanolic and aqueous extracts of fluted pumpkin (Telfairia occidentalis) leaves against garlic-induced oxidative stress. J Med Food 8: 560-563.

7. Fasuyi AO (2006) Nutritional potentials of some tropical vegetable leaf meals: chemical charaterization and functional properties. Afri J Biotech 5: 49-53.

8. Kayode OT, Kayode AA, Odetola AA (2009) Therapeutic effect of Telfairia occidentalis ameliorates oxidative brain damage in malnourished rats. Int J Biol Chem 4: 10-18.

9. Emeka EJI, Obidoa O (2009) Some biochemical, haematological and histological responses to a long term consumption of Telfairia occidentalissupplemented diet in rats. Pak J Nutr 8: 1199- 1203.

10. Adaramoye OA, Achem J, Akintayo OO, Fafunso MA (2007) Hypolipidemic 
Citation: Adepoju-Bello AA, Okeke CP, Bamgbade I, Oguntibeju OO (2013) Determination of the Concentration of Selected Heavy Metals in Indigenous Plant: Telfairia occidentalis. Altern Integ Med 2: 137. doi:10.4172/2327-5162.1000137

Page 4 of 4

effect of Telfairia occidentalis (fluted pumpkin) in rats fed a cholesterol-rich diet. J Med Food 10: 330-336.

11. Williams IO, Parker RS, Swanson J (2009) Vitamin a content of south-east Nigerian vegetable dishes, their consumption pattern and contribution to vitamin A requirement of pregnant women in Calabar Urban, Nigeria. Pak J Nutr 8: 1000-1004.

12. Oboh G, Nwanna EE and Elusiyan CA (2006) Antioxidant and antimicrobial properties of Telfairia occidentalis fluted pumpkin leaf extracts. J Pharmacol Toxicol 1: 167-175.

13. Ola FL, Oboh G (2001) Nutrient distribution and zinc bioavailability. Estimation in some tropical edible mushrooms. Nahrung 45: 67-68.

14. Alada AR (2000) The haematological effects of Telfairia occidentalis diet preparation. Afri J Biomed Res 3: 185-186.

15. Ferner D J (2001) Toxicity of heavy metals. eMed J 2: 1-5.

16. Zheng N, Wang Q, Zheng D (2007) Health risk of $\mathrm{Hg}, \mathrm{Pb}, \mathrm{Cd}$, Zn, and Cu to the inhabitants around Huludao Zinc Plant in China via consumption of vegetables. Sci Total Environ 383: 81-89.

17. Adepoju-Bello AA, Issa OA, Oguntibeju OO, Ayoola GA, Adejumo OO
(2012) Analysis of some selected toxic metals in registered herbal products manufactured in Nigeria. Afri J Biotech 11: 6918-6922.

18. Cai SW, Yue L, Hu ZN, Zhong XZ, Ye ZL, et al. (1990) Cadmium exposure and health effects among residents in an irrigation area with ore dressing wastewater. Sci Total Environ 90: 67-73.

19. Balarama Krishna MV, Karunasagar D, Arunachalam J (2003) Study of mercury pollution near a thermometer factory using lichens and mosses. Environ Pollut 124: 357-360.

20. British Pharmacopoeia (2005) Atomic spectrophotometry: emmision and absorption, Appendix IID, CD.

21. Poppiti JA, Charles S (1994) Practical techniques for laboratory analysis. (2ndedn), CRC Press 123-130.

22. Cui YJ, Zhu YG, Zhai RH, Chen DY, Huang YZ, et al. (2004) Transfer of metals from soil to vegetables in an area near a smelter in Nanning, China. Environ Int 30: 785-791.

23. Ding AF, Pan GX (2003) Contents of heavy metals in soils and Chinese cabbages from some urban vegetable fields around Nanjing and human health risks. Ecol Environ 12: 409-411.

24. European Economic Commission Regulation (EEC) 2006 No 2092/91. 